Volume 3 Nomor 2, 2018, hlm 101-106

DOI: https://doi.org/10.29210/300327800

ISSN: 2502-079X (Print)

ISSN: 2503-1619 (Electronic)

Info Artikel:

Diterima: $15 / 11 / 2018$

Direvisi: 5/12/2018

Dipublikasikan: 17/12/2018

Dipublikasikan oleh:

Indonesian Institute for Counseling, Education and Therapy (IICET)

Akses Online :

http://jurnal.iicet.org/index.php/jrti

\title{
Meningkatkan kemampuan mengenal angka pada anak usia dini melalui permainan ular tangga di taman kanak-kanak sadar bakti sungai aur pasaman barat
}

\author{
Yuliarti \\ Universitas Negeri Padang \\ e-mail: yuliarti1981@gmail.com
}

\begin{abstract}
The goal to be achieved from this study is to improve the ability to recognize numbers in children through a snake ladder game in Sadar Bakti Kindergarten, Sungai Aur Pasaman Barat. The type of research is Classroom Action Research conducted by means of cycles, namely two cycles each cycle of three meetings. The results of the study showed that the ability to recognize numbers in children had not yet developed and continued improvement in the first cycle through snake ladder activities using various media. In cycle II achieve optimal results with excellent results. Thus it was concluded that the snake ladder game with various media can improve the ability to recognize numbers in children in the Sadar Bakti Kindergarten, Sungai Aur Pasaman Barat.
\end{abstract}

Keywords: Knowing Numbers, Snakes and ladders game

\section{PENDAHULUAN}

Anak Taman Kanak-kanakadalah bagian dari anak usia dini pada jalur formal, anak usia dini mempunyai batasan usia tertentu, karakteristik yang unik dan berada pada proses perkembangan sangat pesat bagi kehidupan berikutnya.. Masa usia dini merupakan periode emas (golden age) bagi perkembangan anak untuk memperoleh proses pendidikan.periode ini adalah tahun-tahun berharga bagi seorang anak untuk menggali berbagai macam fakta dilingkungannya sebagai stimulans terhadap perkembangan kepribadian.psikomotor,kognitif maupun sosialnya.

Yulsyofriend (2013), Anak Usia Dini adalah sosok individu yang sedang menjalani suatu proses perkembangan dengan pesat dan fundamental bagi kehidupan selanjutnya. Anak Usia Dini 
berada pada rentang usia 0-8 tahun. Pada masa ini proses pertumbuhan dan perkembangan dalam berbagai aspek sedang mengalami masa yang cepat dalam rentang perkembangan hidup manusia.

Anak memiliki karakteristik yang berbeda dengan orang dewasa dalam berprilaku, dengan demikian dalam hal belajar anak juga memiliki karakteristik yang tidak sama pula dengan orang dewasa. Karakteristik cara belajar anak merupakan fenomena yang harus dipahami dan dijadikan acuan dalam merencanakan dan melaksanakan pembelajaran untuk anak usia dini.

Suryana (2013) mendiskripsikan karakteristik anak usia dini sebagai berikut: 1) Anak bersifat egosentris, pada umumnya anak masih bersifat egosentris, ia melihat dunia dari sudut pandang dan kepentingannya sendiri. 2) Anak memiliki rasa ingin tahu, anak berpandangan bahwa dunia ini dipenuhi hal-hal yang menarik dan menakjubkan. 3) Anak besifat unik, anak memiliki keunikan sendiri seperti dalam gaya belajar, minat dan latar belakang keluarga.4) Anak kaya imajinasi dan fantasi, anak memiliki dunia sendiri berbeda dengan orang di atas usianya, mereka tertarik dengan hal-hal yang bersifat imajinasi sehingga mereka kaya dengan fantasi. 5) Anak memiliki daya konsentrasi pendek, pada umumnya anak sulit untuk berkosentrasi pada sesuati kegiatan dalam jangka waktu yang lama.

Anak usia Taman Kanak-kanak tidak saja dipersiapkan untuk memasuki jenjang pendidikan Sekolah Dasar (SD), tetapi yang lebih utama adalah supaya anak memperoleh rangsanganrangsangan kemampuan dasar terhadap perkembangan bahasa, kognitif, fisik motorik dan seni, serta pengembangan pembiasaan yang terdiri dari nilai-nilai agama, sosial, emosional dan kemandirian.

Pendidikan Taman Kanak-kanak merupakan salah satu bentuk Pendidikan Anak Usia Dini (PAUD) formal yang sesuai dengan UU No. 20 tahun 2003. Pendidikan Taman Kanak-kanak menggunakan program pengembangan prilaku/pembiasaan dan kemampuan dasar pada diri anak secara optimal.Taman Kanak-kanakadalah pendidikan yang ditujukan bagi anak-anak usia 4-6 tahun. Pada masa ini anak memasuki tahap praoperasional konkrit dalam berfikir dari aktivitas belajar di Taman Kanak-kanak.Pada masa ini sifat egosentris pada anak semakin nyata. Anak mulai memiliki perspektif yang berbeda dengan orang lain yang berada disekitarnya.

Pembelajaran di Taman Kanak-kanak dilakukan sambil bermain. Bermain merupakan cara yang paling baik untuk mengembangkan kemampuan mengenal angka pada anak didik. Sebelum bersekolah, bermain merupakan cara alamiah untuk menemukan lingkungan, orang lain, dan diri sendiri (Rakimahwati. R, 2018; Putri, M., Rakimahwati, R., \& Zulminiati. Z, 2018). Pada prinsipnya, bermain mengandung rasa senang dan tanpa paksaan serta lebih mementingkan proses dari pada hasil akhir (Rakimahwati, R., Lestari, N. A., \& Hartati. S, 2018). Perkembangan bermain sebagai cara pembelajaran hendaknya disesuaikan dengan perkembangan umur dan kemampuan anak didik, yaitu berangsur-angsur dikembangkan dari bermain sambil belajar (unsur bermain lebih besar) menjadi belajar sampai bermain (unsur belajarnya lebih banyak). Dengan demikian, anak didik tidak akan canggung lagi menghadapi cara pembelajaran ditingkat-tingkat berikutnya.

Dunia anak adalah dunia bermain.Bagi anak-anak, kegiatan bermain selalu menyenangkan.Bermain menurut Sudono (2000) adalah suatu kegiatan yang dilakukan dengan alat atau tanpa menggunakan alat yang menghasilkan pengertian atau memberikan informasi, memberikan maupun mengembangkan imajinasi anak.

Menurut Ariesta (2009) alat permainan adalah segala sesuatu yang dapat digunakan sebagai sarana atau atau alat permainan yang mengandung nilai pendidikan dan dapat mengembangkan seluruh aspek kemampuan anak, baik berasal dari lingkungan alam sekitar maupun yang sudah dibuat (dibeli).

Unsur yang ada di dalam matematika adalah kemampuan membilang. Bilangan atau biasa disebut dengan angka tidak terlepas dari matematika.Bilangan memiliki beberapa bentuk/ tampilan (representasi) yang saling berkaitan diantaranya benda nyata, model mainan, ucapan, simbol (angka atau kata). Dalam pembelajaran matematika mengenal konsep bilangan tidak hanya tampilan bahasa lisan saja tetapi harus diiringi dengan tampilan model/benda mainan ataupun tampilan gambar (Rakimahwati., R \& Marlina., S, 2018 ; Rakimahwati, R. 2017).

Pengenalan angka pada anak usia dini disebabkan karena setiap bilangan yang dilambangkan dalam bentu angka, sebenarnya merupakan konsep abstrak. Pembelajaran matematika mengenal konsep bilangan tidak hanya tampilan bahasa lisan saja tetapi harus diiringi dengan tampilan model/benda mainan ataupun tampilan gambar. Konsep abstrak ini merupakan hal yang sulit untuk anak Taman Kanak-kanak memahami secara langsung sehingga diperlukan suatu upaya untuk meningkatkan kemampuan anak dalam mengenal angka. 
Pengembangan pengenalan angka ini dapat dilaksanakan dengan berbagai cara termasuk melalui permainan. Permainan mengenal angka di Taman Kanak-kanak tidak hanya terkait dengan kemampuan kognitif saja, tetapi juga kesiapan mental sosial dan emosional karena itu dalam pelaksanaannya harus dilakukan secara menarik, bervariasi dan menyenangkan. Permainan mengenal angka merupakan pemberian pengalaman belajar dalam bentuk permainan, dengan cara melatih keterampilan penglihatan, gerak dan ingatan, memberikan rangsangan dan tantangan serta konsentrasi dan ketangkasan. Oleh sebab itu Guru Taman Kanak-kanak harus dapat mengembangkan pemahaman anak, hal tersebut dapat melalui permainan yang asyik dan menarik baik dari segi bentuk dan ukuran dari alat-alat yang digunakan bermain mencangkup penggunaan simbol, tindakan atas objek yang punya arti untuk diri anak.Bermain tidak terikat dengan realitas, maka dimungkinkan bagi anak untuk merubah-rubah minatnya dimana hal itu juga penting untuk perkembangan anak.

Mengembangkan kemampuan mengenal angka pada anak anak Taman Kanak-kanaktidak dilakukan dalam jangka waktu pendek, yang harus dilakukan secara bertahap dalam jangka waktu yang lama, serta dibutuhkan media yang kongkrit untuk membantu proses pembalajaran mengenal bilangan. Mengenal angka menurut Sudaryanti (2006) anak dapat diajarkan dengan menghitung jari, lalu melihat gambar LKA yang sudah ada angkanya, atau mengurutkan angka sewaktu anak bermain dalam lingkungannya.Pada bagian dada anak ditempeli kartu angka dalam ukuran besar dan anak diminta untuk berdiri sesuai posisi urutan angka yang ditempel pada masing- masing dada anak.

Pengembangan mengenal angka merupakan daya untuk melakukan suatu tindakan sebagai hasil dari pembawaan dan latihan. Seseorang dapat melakukan sesuatu karena adanya kemampuan yang dimilikinya. Kemampuan ini ialah potensi seseorang yang merupakan bawaan sejak lahir serta di kembangkan dengan adanya pembiasaan dan latihan, sehingga ia mampu melakukan sesuatu.

Berdasarkan observasi awal yang telah dilakukan di TK Sadar Bakti Sungai Aur Pasaman Barat menunjukkan bahwa kemampuan mengenal angka masih rendah adalah kognitif anak Kelompok B dalam mengenal angka.Anak dalam menyebutkan urutan angka 1-10, mengenal angka dengan benda-benda 1-10 serta membuat urutan angka 1-10, dianggap sulit oleh anak. Karena adanya kesenjangan yang terjadi didalam pelaksanaan proses pembelajaran dengan keadaan yang sebenarnya dimana didalam mengenal angka peneliti cendrung menggunakan media papan tulis, atau pada saat mengenal angka biasanya pendidik langsung menggunakan symbol angka yaitu 1,2, 3 dan seterusnya dan pendidik menulis angka 1 di papan tulis lalu anak-anak menirukan menulis angka 1 seperti yang dicontohkan. Ketika anak menghitung media yang digunakan langsung dengan gambar, jadi anak menghitung jumlah gambar lalu dihubungkan dengan angka yang sesuai dengan cara membuat garis untuk menghubungkan jumlah gambar dengan angka.buku tulis untuk menuliskan angka tersebut tanpa menggunakan benda-benda nyata atau kongkrit serta gambar yang mewakili angka tersebut. Sehingga anak cendrung menghapal urutan angka namun tidak mengenal bentuk angkanya, sehingga dari penelitian ini dapat dilakukan perubahan terhadap metode penyampaian peneliti dalam mengembangkan kemampuan anak dalam mengenal anagka dengan menggunakan media pembelajaran yang menarik.

Kemampuan mengenal angka anak masih sulit bagi anak-anak untuk memahaminya. Karena dalam proses pembelajaran di Taman Kanak-kanak anak-anak belum bisa memahami dengan cara yang tepat dan benar. Kurangnya kemampuan guru dalam menciptakan metode dan media yang menarik yang dapat meningkatkan kemampuan anak dalam mengenal angka.Padahal mengenal angkamerupakan hal yang penting dalam mengembangkan kemampuan anak.Maka untuk mengatasi hal tersebut penulis merancang sebuah pembelajaran melalui permainan yang menarik yang sesuai dengan prinsip pembelajaran di Taman Kanak-kanak yaitu bermain sambil belajar dan belajar seraya bermain.

Kurangnya kemampuan guru dalam menciptakan media yang menarik, maka untuk mengatasi hal tersebut peneliti merancang sebuah permainan yaitu permainan ular tangga.Permainan ular tangga merupakan suatu permainan yang dapat mengembangkan kemampuan anak terutama dalam mengenal angka. Ular tangga yang disediakan berwarna-warni sehingga dapat menarik perhatian anak dan menyenangkan dengan tanpa disadari ternyata ia dapat mengenal angka, peneliti yakin dengan permainan ular tangga dapat meningkatkan kemampuan mengenal angka. 


\section{METODOLOGI PENELITIAN}

Penelitian ini dilakukan menggunakan penelitian tindakan kelas. Penelitian ini dilakukan di Taman Kanak-kanak Sadar Bakti yang terletak di Kejorongan Kasik Putih, Kecamatan Sungai Aur, Kabupaten Pasaman Barat.Waktu untuk mengadakan penelitian ini akan dilaksanakan pada Semesetr I yaitu bulan Juli-Desember Tahun Pelajaran 2018/2019 di Taman Kanak-kanak Sadar Bakti Sungai Aur Pasaman Barat. Subjek penelitian adalah guru dan anak-anak didik Kelompok B3 Taman Kanak-kanak Sadar Bakti Sungai Aur Pasaman Barat dengan jumlah 15 orang yang terdiri dari 5 (lima) anak didik perempuan dan 10 (sepuluh) anak didik laki-laki. Data yang diperoleh selama penelitian berlangsung akan dianalisa dengan teknik persentase.

\section{HASIL}

Berdasarkan penelitian yang telah peneliti lakukan, dimana menurut peneliti dari masingmasing siklus didapatkan bahwa melalui permainan ular tangga dapat meningkatkan kemampuan mengenal angka pada anak di Taman Kanak-kanak Sadar Bakti Sungai Aur Pasaman Barat,berkembangnya kemampuan mengenal angka pada anak melalui permainan ular tangga pada masing-masing aspek dengan kriterian ketuntasan maksimum (KKM) sebesar 75\%, hal ini terlihat dari tingkat perkembangan anak dari masing-masing siklus yang terus meningkat.

Untuk lebih jelasnya analisis data peningkatan kemampuan mengenal angka pada anak melalui permainan ular tangga dengan nilai berkembang sangat baik dapat dijabarkan sebagai berikut:

Tabel 1. Persentase Hasil Observasi Meningkatkan KemampuanMengenal Angka Pada Anak Melalui Permainan Ular TanggaDengan Nilai Berkembang Sangat Baik

\begin{tabular}{cllllll}
\hline No & \multicolumn{3}{c}{ Aspek yang dinilai } & Siklus I & Siklus II & Keterangan \\
\hline $\mathbf{1}$ & $\begin{array}{l}\text { Anak dapat menyebutkan angka } \\
\text { permainan ular tangga }\end{array}$ & $1-10$ & melalui & $40 \%$ & $87 \%$ & Meningkat \\
$\mathbf{2}$ & $\begin{array}{l}\text { Anak dapat menunjukkan angka } \\
\text { permainan ular tangga } \\
\text { Anak dapat mencocokkan angka dengan benda-benda } \\
1-10 \text { melalui permainan ular tangga }\end{array}$ & $13 \%$ & $80 \%$ & Meningkat \\
\hline
\end{tabular}

Berdasarkan tabel di atas dapat dilihat peningkatan kemampuan mengenal angka melalui permainan ular tangga dengan nilai berkembang sangat baik pada masing-masing indikator.Pada siklus I nilai berkembang sangat baik pada aspek pertama anak dapat menyebutkan angka 1-10 melalui permainan ular tanggaberjumlah 6 orang dengan persentase $40 \%$ dan meningkat pada siklus II menjadi 13 orang dengan persentase $87 \%$. Pada aspek kedua anak dapat menunjukkan angka 1-10 melalui permainan ular tanggaberjumlah 6 orang dengan persentase $40 \%$ dan meningkat pada siklus II menjadi 12 orang dengan persentase $80 \%$. Pada aspek ketiga anak dapat mencocokkan angka dengan benda-benda 1-10 melalui permainan ular tanggaberjumlah 2 orang dengan persentase $13 \%$ dan meningkat menjadi 12 orang dengan persentase $80 \%$.

Untuk lebih jelasnya dapat dilihat pada grafik di bawah ini: 


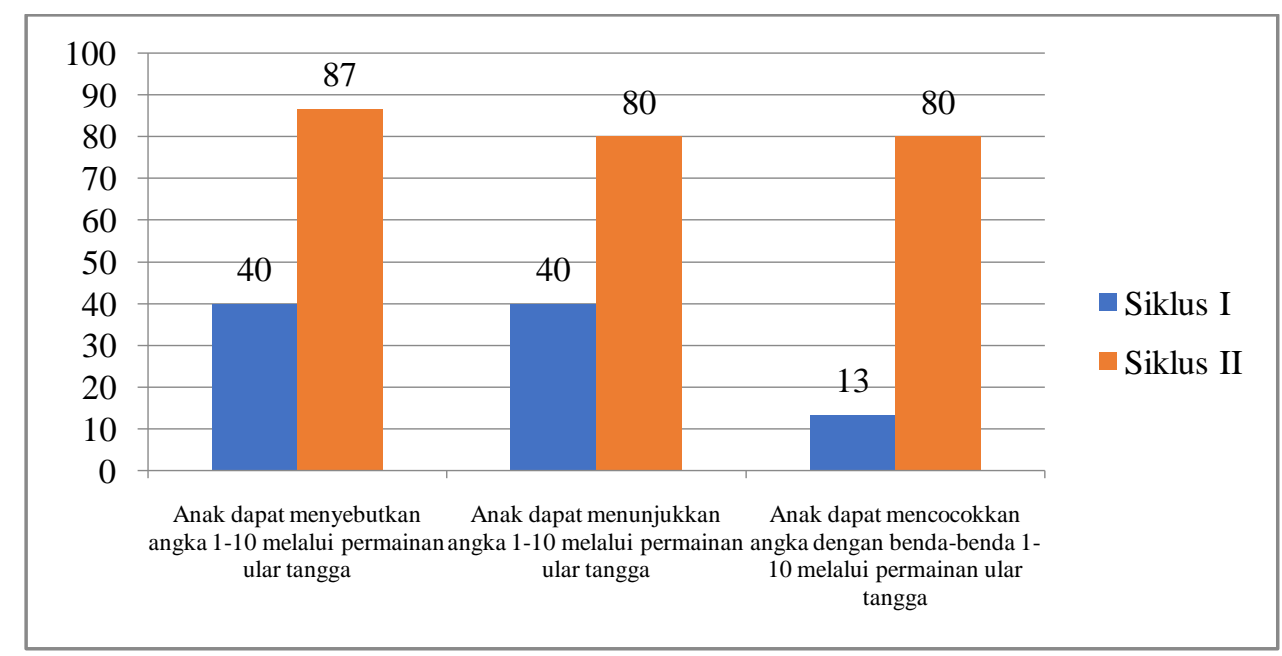

Gambar 1. Persentase Hasil Observasi Meningkatkan Kemampuan Mengenal Angka Pada Anak Melalui Permainan Ular Tangga Dengan Nilai Berkembang Sangat Baik

\section{PEMBAHASAN}

Hasil yang diperoleh mengenai peningkatan kemampuan anak pada aspek yang di nilai meliputi anak dapat menyebutkan angka 1-10 melalui permainan ular tangga, anak yang mendapat nilai Berkembang Sangat Baik pada siklus I sebesar $40 \%$ dan mengalami kenaikan pada siklus II sebesar $87 \%$ yang menandakan adanya peningkatan kemampuan anak pada aspek yang dinilai, hal ini sesuai dengan pendapat Sujiono (2012:11.7) tentang mulainya konsep angka. Konsep angka melibatkan pemikiran tentang: "beberapa jumlahnya atau berapa banyak termasuk menghitung, mengelompokkan dan membandingkan. Menghitung merupakan cara belajar mengenai nama angka kemudian menggunakan nama angka tersebut untuk mengidentifikasi jumlah benda.

Aspek anak dapat menunjukkan angka 1-10 melalui permainan ular tangga, anak yang mendapat nilai Berkembang Sangat Baik pada siklus I sebesar 40\% dan mengalami kenaikan pada siklus II sebesar $80 \%$ yang menandakan terjadi peningkatan pada aspek yang dinilai.

Aspek penilaian yang terakhir adalah anak dapat mencocokkan angka dengan benda-benda 110 melalui permainan ular tangga dimana pada siklus I didapatkan nilai Berkembang Sangat Baik sebesar $13 \%$ dan mengalami kenaikan menjadi $80 \%$ pada siklus II yang menandakan peningkatan kemampuan anak dalam mengenal angka.

Berdasarkan aspek yang dinilai maka pada masing-masing aspek anak yang mendapatkan nilai rata-rata Berkembang Sangat Baik pada akhir siklus I dengan persentase 31\% dan mengalami kenaikan pada akhir siklus II sebesar $82 \%$, hal ini peneliti membuat perbaikan alat permainan yang sesuai dengan pendapat Hartati (2005:85) menyatakan bahwa bermain adalah suatu proses yang berlangsung dan spontan yang dilakukan seorang anak bersama orang lain atau dengan bendabenda disekitarnya dengan senang, sukarela menggunakan perasaan, tangan atau seluruh anggota tubuhnya.

\section{SIMPULAN DAN SARAN}

Berdasarkan hasil penelitian dan pembahasan yang telah diuraikan pada bab sebelumnya, maka dapat diambil kesimpulan dan saran sebagai berikut : Meningkatkan kemampuan mengenal angka pada anak merupakan suatu kegiatan yang terpadu, yang tercakup beberapa aspek yaitu menyebutkan angka 1-10 melalui permainan ular tangga, menunjukkan angka 1-10 melalui permainan ular tangga dan mencocokkan angka dengan benda-benda 1-10 melalui permainan ular tangga. Hasil rata-rata yang diperoleh mengenai meningkatkan kemampuan mengenal angka pada anak masing-masing indikator yang telah ditetapkan maka anak yang mendapat nilai berkembang 
sangat baik pada kondisi awal 0\%, sedangkan pada siklus I mengalami kenaikan $31 \%$ dan mengalami kenaikan yang sangat bagus pada siklus II menjadi 82\%.Ini menandakan bahwa dengan permainan ular tangga dapat meningkatkan kemampuan mengenal angka pada anak.Sedangkan rata-rata pada penilaian Belum Berkembang pada masing-masing indikator yang telah ditetapkan dimana pada kondisi awal $80 \%$ mendapat nilai belum berkembang, pada akhir siklus I mengalami penurunan menjadi $22 \%$ dan anak yang mendapat nilai belum berkembang pada akhir siklus II $0 \%$.Hal ini menandakan dengan pendekatan yang rutin dan sungguh-sungguh disertai motivasi yang diberikan guru untuk lebih meningkatkan kemampuan mengenal angka pada anak sangat berpengaruh terhadap kemampuan mengenal angka sehingga anak meningkat kemampuannya.

Berdasarkan kesimpulan di atas, ada beberapa saran yang ingin diuraikan sebagai berikut :Kepala Sekolah sebaiknya menyediakan alat-alat permainan yang dapat meningkatkan kemampuan mengenal angka pada anak. Bagi Guru hendaknya menggunakan media pembelajaran salah satunya dengan permainan ular tangga untuk meningkatkan kemampuan mengenal angka pada anak, dengan begitu anak tidak akan merasa jenuh dalam belajar serta tujuan pembelajaran akan tercapai secara maksimal.Bagi anak Taman Kanak-kanak Sadar Bakti Sungai Aur Pasaman Barat diharapkan dapat mengikuti pembelajaran dengan baik sehingga proses pembelajaran dapat berjalan dengan efektif.Diharapkan kepada Dinas terkait untuk memberikan perhatian yang besar dalam peningkatan kemampuan mengenal angka pada anak di Taman Kanak-kanak Sadar Bakti Sungai Aur Pasaman Barat pada khususnya dan Kecamatan Sungai Aur pada umumnya.Bagi masyarakat diharapkan dapat menggunakan skripsi ini sebagai sumber ilmu pengetahuan guna menambah wawasan.

\section{DAFTAR PUSTAKA}

Arikunto. (2006). Tentang Penelitian Tindakan Kelas. Jakarta: Bumi Aksara

Ariesta. (2009). Alat Permainan Edukatif Lingkungan Sekitar. Bandung : PT. Sandarta Sukses

Hartati, Sofia. (2005). Perkembangan Belajar Pada Anak Usia Dini.Jakarta:Depdiknas.

Putri, M., Rakimahwati, R., \& Zulminiati, Z. (2018). Efektivitas Penerapan Metode Bermain Peran Makro terhadap Perkembangan Bahasa Lisan Anak di Taman Kanak-kanak Darul Falah Kota Padang. Journal of Studies in Early Childhood Education (J-SECE), 1(2), 171-179.

Rakimahwati, R. (2018). Pelatihan Pembuatan Boneka Jari Bergambar dalam Meningkatkan Kemampuan Membaca Anak Usia Dini di Kecamatan V Koto Kampung Dalam Kabupaten Padang Pariaman. Early Childhood: Jurnal Pendidikan, 2(2b), 1-11.

Rakimahwati, R. (2017). Interactive Game Influences Based on Inquiry Learning Model Towards The Ability of Reading in Kindergarten in Padang. In International Conference of Early Childhood Education (ICECE 2017). Atlantis Press.

Rakimahwati, R., Lestari, N. A., \& Hartati, S. (2018). Pengaruh Kirigami Terhadap Kemampuan Motorik Halus Anak di Taman Kanak-Kanak. Jurnal Obsesi: Jurnal Pendidikan Anak Usia Dini, 2(1), 102-110.

Rakimahwati, R., \& Marlina, S. (2018). Pengaruh Media Busy Book Terhadap Kemampuan Berhitung Anak Usia Dini Di Taman Kanak-Kanak Fadhilah Amal 3 Padang. Jurnal Usia Dini, 4(2), 8-17.

Sudaryanti. (2006). Pengenalan Matematika Anak Usia Dini. Yogyakarta: FIP Universitas Negeri Yogyakarta

Sujiono. (2008). Metode Pengembangan Kognitif. Jakarta: UT

Sudono, Anggani. (2000). Sumber Belajar dan Alat Permainan.Jakarta : PT. Grasindo

Suryana, Dadan. (2013). Pendidikan Anak Usia Dini. Padang : UNP Press

Yulsyofriend. (2013). Permainan Membaca dan Menulis Anak Usia Dini. Padang: Sukabumi Press 